\title{
Ellipsis
}

2016

\section{Life Left on the Shore}

Sarah R. Warner

University of New Orleans

Follow this and additional works at: https://scholarworks.uno.edu/ellipsis

\section{Recommended Citation}

Warner, Sarah R. (2016) "Life Left on the Shore," Ellipsis: Vol. 43 , Article 20.

DOI: https://doi.org/10.46428/ejail.43.20

Available at: https://scholarworks.uno.edu/ellipsis/vol43/iss1/20

This Fiction is brought to you for free and open access by the Department of English and Foreign Languages at ScholarWorks@UNO. It has been accepted for inclusion in Ellipsis by an authorized editor of ScholarWorks@UNO. For more information, please contact scholarworks@uno.edu. 


\title{
Life Left on the Shore
}

\author{
Sarah R. Warner
}

"I went out on the boat yesterday."

The hospital room was stark white, the air thick with the sting of antiseptic and bleach. Dakota looked down at her father's hand, his blue veins prominent even through his tanned skin. An IV ran from one vein to the post at his bedside that steadily dripped a clear liquid, each drop another second that he lay without moving, his eyes closed and chest rising and falling steadily.

"Hayden came with me," she said quietly. "I know you don't like it when I go alone." He didn't respond, though she didn't expect him to. She never did. The moments when he was coherent were few and far between. They were interspersed with long periods of silence or confusion, his brown eyes tired and listless as they moved around the room, often passing over her as though she were just another piece of furniture against the wall.

"She wouldn't stay on the boat. Said it was too nice to not get in the water." Her eyes moved away from his hand and followed the strong curve of his arm until they landed on his face. His chin was prickly with stubble, his cheekbones more prominent than she remembered them being. She frowned slightly, reaching out and pressing her hand on top of his.

"She tried to make me join her." She struggled to ignore how much colder his skin was than her own. Here she paused, her eyes moving to the steady drip of the saline bag as it counted the seconds that passed by. "I tried. I thought you would want to know that."

The setting sun cast strange shadows on the wall in front of her, a small breeze stirring the dark hair that stuck to her neck despite the constantly cool temperature of the hospital. She glanced up when a nurse knocked before entering the room, her eyes tired as she looked at the open window behind Dakota, a frown tugging on her lips.

"I've told you before not to open that window," she said sternly, though there was no force behind her words. Dakota shrugged, glancing back at her father.

"He would like the fresh air," she responded simply. She imagined that the salt from the sea came in with the breeze, stirring his consciousness just slightly every time it passed over his still face. He would have hated to be cooped up like this; he'd said so in one of his rare moments of lucidity.

"It's policy," the nurse continued, pausing next to her father's body as she checked his vitals, replacing his IV and the bag that it connected to. Dakota watched her in silence, her arms folded tightly across her chest. She thought for a moment her father's finger had twitched, but his face remained still and pallor. 
"How is he doing?" Dakota asked finally, and the pity in the nurse's face as she turned her eyes towards her was enough to make her bristle. She lowered her hands to her sides, gripping the edges of the metal chair she sat in.

"Nothing's changed," was her only reply, and Dakota nodded, waiting until she closed the window and reminded her that visiting hours were almost over before releasing her grip on the chair. She stood up slowly, her legs screaming in protest after having been in the same position for hours on end. She turned back to the window, pulling it open once more. The breeze cooled the tears on her cheeks as it passed by.

She hoped he could see the beach in the distance when he opened his eyes. She hoped it was a comfort rather than a burden to see the thing that he had always loved so much, despite the fact that he was unable to enjoy it from the hospital bed. She hoped he could smell the salt from the sea in his dreams.

She turned back to his still figure in the bed, leaning down and pressing her lips to his forehead before grabbing her jacket and leaving the room.

The water lapped softly at the sides of the boat as Dakota stared down at her feet, hanging just inches above the surf. The boat rocked her gently, a soothing motion that she had fallen asleep to many nights when she was younger.

"Come on, Dakota," Hayden called from the water. Her long blonde hair floated on the surface of the waves, the water giving it a green tint that reminded Dakota of algae. Her long legs stretched out behind her as she swam back towards the boat, gripping the edge next to Dakota's legs, propping herself up on her elbows and looking up at her with a smile on her lips that didn't quite reach her eyes.

"The water feels nice," she tried again, and Dakota looked away from her, staring instead at the pieces of wood and leaves that floated by beneath her feet. She watched a small twig until the gentle tug of the waves pulled it beyond her line of sight. She could feel Hayden's eyes on her, soft and yet somehow piercing, and she stiffened slightly, glancing back at her from the corner of her eyes.

"I'm fine," she said simply, her voice barely audible above the wind that fluttered the sails above their heads. The sound made her chest tighten slightly as she imagined the boat floating out to sea with her still on it, trapped, the small vessel somehow dragging the anchor along the sand with it.

Her feet dipped slightly in the water, the sudden contact making her jump back as Hayden tugged herself up, causing the boat to lean slightly to the side. Dakota quickly pulled her feet away from the edge, turning and planting them firmly on the wooden deck instead as Hayden plopped down on the plastic chair that sat near her, dripping water.

"I promised Sean that I would meet him by five," Hayden said as she began to wring out her hair, a puddle quickly forming beneath her feet. Dakota leaned forward slightly, a frown on her lips as she spoke.

"Which one is he again?" she asked.

Hayden looked at her, her hands loosening their grip on her hair as she spoke slowly. 
"Hot brunette. About 6'5. Eyes so blue you get lost in them." At Dakota's blank stare, Hayden shook her head, a sigh escaping her lips as she stood up and wrapped herself in a towel.

"I introduced you to him last week at that party at Whitney's house." A face made its way into Dakota's mind, though it was vague and blurry, as were many of the boys that Hayden flirted with and eventually dumped when they went home from vacation. She often dated tourists; they were perfect for a quick fling, something that her friend had been fond of since their days in high school.

"Right," was Dakota's only reply, and Hayden sighed again, settling back down into the chair.

"We're going to have dinner on the pier, and then we were thinking of hitting up that party at Nicole's house around 10. Do you want to come with?" The sincerity in Hayden's voice made Dakota pause, looking back at her from where her gaze had wandered to the water.

She frowned, glancing down at her bare feet, focusing on the bright red of her nail polish instead of answering. She rarely wanted to go to parties; she'd only started going as a way to keep an eye on Hayden, who had a tendency to drink too much and then fall all over the first guy who called her pretty. What had begun as a precaution had turned into a job of sorts, and after several close calls with both alcohol and boys who couldn't keep their hands to themselves, Dakota was reluctant to let her friend out of her sight.

Her mind turned inadvertently towards her father, lying alone and still in his hospital bed, no doubt deprived again of the sea air that he loved so much. The image made her chest tighten, guilt settling over her like a blanket as she nodded. Her voice was low as she finally spoke, turning her eyes back to her friend.

"Sure," she said, relaxing slightly when Hayden did, either unaware or uncaring of the hesitation in her voice. "That would be great."

The house was silent as Dakota stepped inside, turning the lock on the door behind her. The only sound in her ears was the steady ticking of the clock that was mounted on the living room wall, directly underneath her father's favorite leather chair. She dropped her keys onto the marbled surface of the kitchen counter as she walked past it, leaving her shoes near the base. Her bare feet sank into the carpet as she walked down the hallway, past the few photographs that lined the walls. Many of them featured only herself and her father; there was only one that featured her mother, a taller, slightly thicker version of herself whose face was only familiar because of its resemblance to her own. Dakota kept her eyes straight ahead, refusing to look at the photo that sat outside her old bedroom, a younger version of herself grinning widely and holding a bass in her tiny hands, with the help of her father's larger ones.

She turned on the light in her bedroom, dust mites floating by silently in the air as she sat down on the bed, the dark green blanket and old posters of bands and movies anything but comforting. He hadn't changed her room when she went to college; he said it was still hers and she was welcome to it anytime. She often came home for breaks, despite the fact that she had an apartment to stay in near 
her university. Still, the room felt largely untouched, reflecting a version of herself that had begun to fade away with age.

Dakota lay back on the bed, closing her brown eyes and listening to the sound of her breath as her chest rose and fell. She imagined her father doing the same, blissfully unaware of the four walls that surrounded him. He would have hated it; sometimes she was grateful for his continuous rest. At least that way he didn't have to feel trapped, didn't have to yearn for the wind and the salt and the waves that he would never experience again.

She opened her eyes when her phone beeped, frowning slightly when she saw the message from Hayden that simply read where $r u$. It took her a moment to realize that it was already 11:15; she had fallen asleep. Hayden was probably already on her third drink, no doubt hanging off of Sean's or someone else's arm. The image was enough to make her sit up, rubbing the sleep from her eyes as she glanced down at her wrinkled jeans and T-shirt. She stood quickly, making her way back out to the living room where she pulled on her shoes before grabbing her keys and stepping outside.

She could see the ocean from the porch. The sound of the waves was loud in her ears as she locked the door behind her, moving quickly towards her car, struggling to push the images of both her father and Hayden lying alone and asleep in her mind. Her father was safe, at least as much as he could be. Hayden, however, was another story.

The party was in full swing by the time she parked on the street. She recognized a few of the girls from high school, who like Hayden had opted to stay near home instead of going to college. She made her way towards the front door, the loud pounding of the music ringing in her ears already.

The smell of sweat and alcohol washed over her like a wave as she pushed her way inside, her eyes quickly scanning the crowd, searching for a head of familiar blonde hair. She ignored the few people who pushed back, instead searching for the kitchen and, subsequently, the booze. That was always where Hayden migrated, despite Dakota's constant pleas for moderation.

Dakota stopped short when she finally managed to break through the crowd, finding herself standing in the hallway next to the kitchen. Hayden was nowhere to be seen. Her breath caught in her throat as she imagined all of the empty bedrooms, all of the nooks and crannies where she could be hidden away. She bit down hard on her lip as she turned away from the kitchen, her voice loud and confident as she struggled to be heard over the pounding of the bass and the drunken revelry.

"Hayden?"

This shouldn't have been her job. God knew Hayden wouldn't appreciate it. She never did, at least not until the next morning when the booze wore off and her head began to clear, snippets of the previous night coming back slowly and painfully. Dakota ducked her head down as she passed a boy that Hayden had dumped last summer, his eyes scanning the crowd for the source of her name. She waited until she had been almost pushed through the sliding glass door to call for her again, the music only slighter softer.

\section{"Hayden!"}


Anxiety began to give way to annoyance as she moved past a group of girls who were taking shots off of each other's chests, a small crowd of boys cheering on the sidelines. She quickly scanned their faces for her friend, but she didn't recognize any of them. She shoved her way through the crowd, ignoring the startled and angry cries that followed her footsteps as she moved away.

"Are you looking for someone?" A voice asked from her right. She stopped, turning to face a boy who was only slightly taller than her, his dark hair sticking up like he had just rolled out of bed. She frowned, glancing behind him at the pool, the splashing of water sending a small chill down her spine.

"Yes," she said simply, turning her gaze back to him, knowing already that her words would be useless. "Blonde. Short. Probably hammered, came here with a brunette guy?" Though her voice inclined, she didn't expect an answer.

"You just described half the girls at this party," was the boy's response, his lips turning up slightly into a smirk. "Say, I don't recognize you. You live around here?"

Dakota's eyes moved around him, scanning the crowd that had congregated in the shallow end of the pool. Her heart rate picked up slightly as she saw a head of blonde hair, though when the girl turned she didn't recognize her face.

"Uh huh," was her disinterested reply, her eyes pausing back on him for only a moment.

"You go to college?" he asked, and she just nodded, stepping slightly to the side and scanning a small group that had gathered near the fence, one of them with their hands tightly gripping the top, struggling to pull themselves up.

"Yeah. A few hours away." Dakota looked back at him, her lips pressed together tightly as he opened his mouth once more. "I'm studying history. Yes, I'm single. No, I don't want a drink. Look, if you can't help me find my friend, then I'm not interested, alright?" Her words were harsh, but she didn't stop to hear his reply before moving away, her mouth dry as she glanced at her watch. It was nearly midnight now; Hayden could have left by now, for all she knew, with Sean or someone else. She was almost back inside when she heard a familiar voice, the words slightly slurred and followed by drunken giggles.

"No more," Hayden laughed, pushing away a drink that an unfamiliar hand tried to give to her. "I shouldn't." Dakota recognized the flirtation in her voice, the way she curved her body towards the two boys, leaning down just far enough to give them a view down her shirt. She frowned slightly, pushing her way towards them.

"Come on, Hailey," one of them said, and Dakota took the drink from his hand, her eyes narrowing slightly in his direction.

"Her name is Hayden, and she said she's not interested," she said simply, dumping the drink out onto the cemented pavement beneath their feet before turning to her friend. Her eyes were red-rimmed, mascara trails only partially wiped off of her cheeks. Dakota touched her arm as her eyes finally focused on her. 
"Kota!" she cried, throwing her arms around her friend. "I didn't think you were coming."

Dakota frowned, the two boys still watching them, neither making a move to leave. She gently pushed her friend away, offering her a thin smile, struggling not to retch at the strong scent of alcohol on her breath.

"Hayden, where's Sean?" she asked, though she felt the answer was obvious.

"He dumped me," Hayden replied, her voice low, and Dakota feared she would unleash another bout of tears, but she looked at the two boys instead. "But Brian and Danny here got me drinks, and made me feel better. Aren't they hot?"

Dakota felt her cheeks redden at her friend's bluntness, stiffening slightly at the smirks on the two boys' lips as they eyed Hayden. She grasped her arm, just nodding.

"I think it's time to go home," she tried, but Hayden shook her head, pulling back.

"The party just started!" she protested, and before Dakota could speak, one of the boys opened his mouth.

"You heard her," he said simply, and the way he reached out and touched Hayden's arm made Dakota's stomach coil. Her cheeks darkened, though from something entirely different this time. She reached back for her friend, who was quickly pulled out of reach by who she assumed was Danny, judging from the gleeful way Hayden said his name as she accepted the drink he offered with his other hand.

"This isn't up for debate," Dakota snapped, reaching out for her friend once more. The other boy, Brian, moved in her way.

"No, it's not," he said, and Dakota looked up at him, her jaw clenched tightly, teeth grinding together. The sound of splashing in the pool behind her grew louder as he moved towards her, forcing her to take a step backwards.

"Hayden, let's go," she tried again, but Hayden ignored her, already moving away on the arm of Danny, her steps unsure. Dakota tried to step after her, but Brian blocked her way once more, his large presence forcing her back another reluctant step. Her hands clenched tightly into fists at her sides. She should have been with her father. He needed her. She should have been at his bedside, not here playing babysitter.

She tried to duck around Brian, but his hands came up to block her before she could take another step forward. She stumbled back from the force of his blow, her feet finding water beneath them instead of solid ground. She opened her mouth, but no sound came out as water instead rushed in.

The sounds of the party faded quickly, replaced by a stillness that she hadn't experienced in a long time. The water closed in around her, and somehow the panic didn't set in right away. She floated in a strange silence, her eyes closed and arms outstretched, searching for something to grab onto.

"Daddy, look at me!"

She splashed in the water, her small arms making waves that many girls her age could only dream of. She could taste the salt water on her tongue, sharp and familiar, as she moved towards the boat. Her father was still on board, his 
tanned skin glistening with sweat as he laughed, watching her as she swam towards him.

Her hands grabbed nothing but water, soft and smooth on her fingertips. Her lungs began to ache, though she couldn't remember why. All she could see was her father, his hands reaching out for her own.

The waves came almost without warning. She was swept underneath the water, the salt burning as it pushed its way down her throat, her nose, into her lungs. She tried to scream, but the waves swallowed her cries, forcing her further down into the dark depths that had never scared her before. She reached a hand up, but the sun's soft glint on the water was as far out of her reach as the sun itself. Her chest burned, her lungs spasming violently as they attempted to expel the ocean from her body.

She lay frozen, her back softly touching the bottom of the pool as the salt water filled her body, pressing her like a weight to the bottom of the ocean. Her eyes closed, her screams dying away as she was pressed down, down, down... Why did this all feel so familiar? Why couldn't she remember how to swim?

She didn't remember a strong pair of arms lifting her from the water. She didn't remember the fear and panic as he tried to bring her back. She only remembered the bruises on her chest and the sharp pain in her throat that lingered long afterwards.

She only remembered never getting in the water with him again.

"Dakota!"

Her eyes opened at the muffled sound of her name, a familiar voice echoing in her ears as she was pulled violently back to reality. Her lungs burned, all of her air expelled from them when she hit the water. She moved quickly, faster than she knew she could, forcing her feet onto the bottom of the pool and pushing herself upwards. The feeling of the water gliding past her bare skin was familiar, even after so many years, and she could only see her father's face in her mind as her head broke the water, gasping air into her lungs as she grasped the side of the pool, her arms trembling and weak.

"She can't swim, you jackass!" She recognized Hayden's voice, her vision blurred by the water droplets that dripped down from her eyelashes. She could see a figure moving towards her, pushing Brian and Danny out of her way. She knelt down next to the pool, grasping Dakota's arms and pulling her up while onlookers stared on, unsure of what to do. Dakota sat in silence as Hayden's arms wrapped around her, warm and trembling.

"She can't swim, and you pushed her in!" she shouted, and Dakota rested her head against her friend's shoulder, a shiver running down her spine as the cool air hit her wet skin. "I can."

"I can swim," she muttered softly, but her voice was lost in the cacophony.

The hospital room was silent. Her father's eyes remained closed, blue veins visible in the lids of his eyes as his chest rose and fell with the beat of his heart. Dakota pressed his hand to her lips, hoping that the gesture would somehow pass through to him wherever he was now. 
He hadn't been coherent for weeks. The nurses had told her that there was still hope, that he could awaken and turn around the damage that had been done to his body, but their eyes were always averted when they spoke to her. Still she visited him every day she could, spending hours next to his almost comatose form, hoping that the smell of the sea and the sound of her voice would somehow bring him back.

"I went out on the boat again yesterday," she said softly, carefully lowering his hand to rest on the bed once more. Her eyes traveled towards the open window, watching the sun as it cast shadows on the walls around them. She closed her eyes, tasting the salt of the sea on her tongue as she spoke.

"I got in the water," she said, and reached out for his hand once more. She imagined that she felt his fingers move beneath her own, but when she opened her eyes, he was still. "I swam." She paused, looking down at his face, pallor and motionless.

"I finally did it." Her voice trailed off into silence as he remained still, the saline bag dripping steadily into his arm. "I thought you would want to know that." 